\title{
Medical Practice and the Law in the Conflict between Traditional Belief and Empirical Evidence: Post-Mortem Caesarean Section in the Nineteenth Century
}

\author{
DANIEL SCHÄFER*
}

In 1819, the French and German press informed the public that at twenty-two minutes past nine on 26 December 1818, the 21-year-old Queen Mary of Spain, who was nine months pregnant with her second child, had died in the course of a convulsive attack. At nine o'clock she was still in good health, sitting up in her bed with some of her servants in attendance when she was suddenly struck by the attack which put an end to her life within twenty-two minutes. Within minutes of her death, the King gave permission to open her body. The child was baptised before being extracted from the womb but was too weak to live and died after a few minutes. It is not known whether the Queen, who had given birth to a child before, had previously suffered from convulsions, or whether these were the cause of her death. Neither do we know whether she had had labour pains, whether she was really dead after several attempts to reanimate her or whether both she and the child could have been saved had a normal delivery been carried out after the attack. However, there is no doubt that this hasty Caesarean section was prompted primarily by theological beliefs rather than by medical necessities. ${ }^{1}$

This brief account of a post-mortem Caesarean section is taken from a textbook on midwifery by the German obstetrician Friedrich Benjamin Osiander which was published in 1821. It highlights the typical circumstances and problems of a surgical intervention which at that time was still mainly influenced by various factors which had nothing to do with medicine. The events at the Spanish Royal Court demonstrate especially the following points:

(1) The child rarely survived the operation.

(2) Post-mortem Caesarean section tended to be carried out mainly in noble houses because of its mythical reputation. The etymological impact of the Caesarean section was primarily due to the numinous, although historically untenable, birth of Julius Caesar, which must be seen as an analogy to the myth of the birth of the deity Aesculapius. Until the seventeenth century it was this etymology, propagated by grammar and historiography,

* Daniel Schäfer, MD, DPhil, Institute of the History of Medicine and Medical Ethics, University of Cologne, Joseph-Stelzmann-Str 9, D-50931

Cologne.

The author wishes to thank Prof. Ulrich Tröhler, MD, $\mathrm{PhD}$, and his colleagues Klaus Bergdolt and Axel Karenberg for their advice and assistance in preparing this study. Special thanks go to Sinéad Donohoe, Judith Steffes and Theo Jaeger, Cologne, for assistance with style and the translation of technical terms.

${ }^{1}$ Friedrich Benjamin Osiander, Handbuch der Entbindungskunst, Tübingen, C F Osiander, 1821, vol. 2, pt 2, pp. 561-2. 


\section{Daniel Schäfer}

which conveyed the ideal of a delivery by Caesarean section. ${ }^{2}$ Furthermore, higher levels of society were also motivated by economic and political factors. If the child was delivered alive it could come into its mother's inheritance, which could be passed on to the father if it subsequently died. ${ }^{3}$

(3) This kind of delivery was strongly promoted in Catholic Spain at the end of the eighteenth century, ${ }^{4}$ mainly because of the influence of the Sicilian theologian Francesco Emanuele Cangiamila and his famous work, Embriologia sacra, which first appeared in 1745. It contained a call for the baptism of the unborn and for the operation to be carried out as a matter of course, even by a midwife or the local priest if no surgeon was available, and even after burial had taken place. He used numerous examples to justify his extreme position. ${ }^{5}$

(4) The influence of Catholicism on legislation relating to obstetrics in certain countries of Continental Europe and in the American colonies was already quite strong. ${ }^{6}$ The important role played by Cangiamila can be seen as no more than a direct result of the call of the Roman Catholic Church for the salvation of souls. This call had already been made by Thomas Aquinas in the Summa theologiae (III, q. 68, 11, 2) and in the Rituale romanum of 1614 (tit. de bapt. parvul.) and had been firmly established as a gravis obligatio (grave obligation) in the Codex Iuris Canonici (can. 746, §4; valid until 1983). According to these rules, the spiritual salvation of the child by immediate baptism was the main goal of such an abdominal delivery. In the case of Queen Mary of Spain, the sacrament was therefore administered as soon as the uterus had been opened, as specified by the French surgeon Pierre Dionis in $1714 .^{7}$

On the other hand, from the sixteenth century onwards, Protestant sources do not refer to the spiritual salvation of the unborn and are much more concerned with the fate of the mother, who may only appear to be dead. ${ }^{8}$

\footnotetext{
${ }^{2}$ See Renate Blumenfeld-Kosinski, Not of woman born, Ithaca and London, Cornell University Press, 1990, pp. 43-153; the survey of the history of the post-mortem Caesarean section in J Paul Pundel, Histoire de l'opération césarienne, Bruxelles, Presses Académiques Européennes, 1969, pp. 15-45; Dyre Trolle, The history of the Caesarean section, Copenhagen, C A Reitzel, 1982, pp. 9-28; Nadja Maria Filippini, La Nascita straordinaria. Tra madre e figlio la rivaluzione del taglio cesaro (sec. XVIII-XIX), Milan, Franco Angeli, 1995; Daniel Schäfer, Geburt aus dem Tod. Der Kaiserschnitt an Verstorbenen in der abendländischen Kultur, Hürtgenwald, Guido Pressler, 1999; idem, 'Embryulkie zwischen Mythos, Recht und Medizin, Zur Überlieferungsgeschichte von Sectio in mortua und Embryotomie in Spätantike und Mittelalter', Medizinhistorisches J., 1996, 31: 275-97.

${ }^{3}$ This is proved, for example, in the documents relating to the death of Margreta, wife of Bo Jonson, in Kalmar 1360; see also O T Hult, 'Ur Kejsaranittels äldre historia', Lychnos, 1939: pp. 243-61, pp. 250f.). The succession within an aristocratic family sometimes depended on the survival of the child.
}

\footnotetext{
${ }^{4}$ See Paula de Demerson, 'La Cesárea post mortem en la España de la ilustración', Asclepio, 1976, 28: 185-233.

${ }^{5}$ Francesco Emanuele Cangiamila, Embryologia sacra sive de officio sacerdotum, medicorum et aliorum circa aeternum parvulorum in utero existentium salutem libri quatuor, Munich, Ingolstadt, Joan. Xaver Crätz, 1764.

${ }^{6}$ Gerard van Swieten, who was reared as a Catholic, called Cangiamila an "egregius auctor"; see idem, Commentaria in Hermanni Boerhaave Aphorismos de cognoscendis et curandis morbis, Taurini, Typographia Regia, 1764, vol. 4, pp. $548-51, \S 1316$. Johann Peter Frank and Friedrich Benjamin Osiander were also clearly influenced by Cangiamila; see Schäfer, Geburt aus dem Tod, op. cit., note 2 above, pp. 237, 239.

${ }^{7}$ Pierre Dionis, Cours d'opérations de chirurgie, Paris, 1714, pp. 136-53.

${ }^{8}$ This is demonstrated, for example, by the midwifery regulations established in Regensburg in 1555 (see Georg Burckhardt, Die deutschen Hebammenordnungen von ihren ersten Anfängen bis auf die Neuzeit, vol. 1, Leipzig, 1912, pp. 142-6, on p. 147) and the Ulmer Kirchenverordnung of 1747
} 


\section{The Post-Mortem Caesarean Section in the Nineteenth Century}

It is likely that a successful operation could have been carried out in the case of the Spanish Queen. The premature baby was obviously delivered immediately after her death, probably by a court surgeon or barber. However, the time lost while royal permission to open the Queen's body was being sought may have played a major role in the child's death. From the sixteenth century onwards, the importance of the time factor in the success or failure of the operation was known. ${ }^{9}$ But the lack of concrete knowledge about the physiological aspects of fetal life gave rise to numerous accounts of unborn children surviving for incredible lengths of time in the dead mother's womb. These continued until well into the eighteenth century. The influence of William Harvey was a main cause of many false interpretations. In his work Exercitationes de generatione animalium, Harvey correctly points out that the child and the mother have two separate blood circulation systems. ${ }^{10}$ But his conclusion that the life of the fetus was independent of that of the mother was based on his belief that he had seen human and animal fetuses which were still alive several hours after the mothers had died.

Leaving theological arguments aside, one of the philanthropic and medico-political goals of the Enlightenment was to improve the success rate of such operations. The debate on apparent death, ${ }^{11}$ which also highlighted the cruel fate of the unborn child buried in the dead mother's womb, was a major factor in the introduction around 1800 in almost all European countries of state laws and municipal decrees based on the ancient Roman legislation Lex Regia. ${ }^{12}$ In the same way, these laws were clearly influenced by the dominant religions of the respective countries. In Sicily and in the kingdom of Greece, ruled by the Catholic Wittelsbach family, failure to carry out the operation could even be punished by death. ${ }^{13}$ In Great Britain no such regulations ever existed; the operation and intrauterine baptism as described in Tristram Shandy by Laurence Sterne tended to be discarded as a laughable Catholic practice. ${ }^{14}$

(No. 7, § 15, pp. $311 \mathrm{ff}$; see Johann Peter Frank, System einer vollständigen medicinischen Polizey, Mannheim, Schwan, 1779, vol. 1, pp. 587-90). See also, Elseluise Haberling, 'Aus der Frühgeschichte des Kaiserschnitts', Die medizinische Welt, 1936, 10 (51): 1860-4, on p. 1863; idem, Beiträge zur Geschichte des Hebammenstandes, I. Der Hebammenstand in Deutschland von seinen Anfängen bis zum Dreißigjährigen Krieg, Berlin, 1940, pp. 22-6.

${ }^{9}$ See Ambroise Paré, La manière de extraire les enfants tant mors que vivans le ventre de la mère (first ed. Paris 1550), in Ambroise Paré, Oeuvres complètes, ed. J Malgaigne, Paris, 1814, vol. 2, pp. 623-32.

${ }^{10}$ Exercitationes de generatione animalium, London, 1651, in Robert Willis (ed.), The works of William Harvey, London 1847, reprint New York and London, Johnson Reprint Corporation, 1965, p. $570 \mathrm{ff}$. See also note 50 below.

11 Surveys in Margrit Augener, 'Scheintod als medizinisches Problem im 18. Jahrhundert', Diss. med., University of Kiel, 1965; Martin Patak, 'Die Angst vor dem Scheintod in der 2. Hälfte des 18.
Jahrhunderts', Diss. med., University of Zürich, 1967; Ingrid Stoessel, Scheintod und Todesangst, vol. 30, Cologne, 1983.

12 Text of the Lex Regia: Digesta XI, 8, 2, in Digesta Justiniani Augusti, ed. Theodor Mommsen, Berlin, Weidmann, 1868, vol. 1, p. 213. Up until the seventeenth century the medical world seems to have ignored the Lex Regia (whose second name Lex caesarea sive Julia was a creation of the early modern era). A list of the sources for legislation is in Schäfer, Geburt aus dem Tod, op. cit., note 2 above, pp. 121-4, 230f.; see also Ignaz Schwarz, 'Der Kaiserschnitt an Todten', Monatsschrift für Geburtskunde und Frauenkrankheiten, 1861, Supplement, 18: 123-9.

${ }^{3}$ See Kurt Quecke, 'Der Kaiserschnitt an der Toten', Ciba Z. (Basel), 1952, 11 (128): 4714.

${ }^{14}$ Tristram Shandy, I 20 and II 19; see also Arthur H Cash, 'The birth of Tristram Shandy: Sterne and Dr. Burton', in Studies in the eighteenth century, papers presented at the David Nicholl Smith Seminary 1966, Canberra, Australian National University Press, 1968, pp. 133-54, on p. 147 f. 


\section{Daniel Schäfer}

Practitioners on the European continent, on the other hand, could be required by law to carry out a post-mortem Caesarean section, depending on the denomination of the ruler of the land, and to be able to prove beyond doubt that the mother was really dead, because, in the eighteenth century especially, occasional cases of the revival of the mother during the course of the operation were known. ${ }^{15}$

Surgeons and obstetricians were therefore confronted with a bizarre situation; they were forced by law to perform the operation and could even face prosecution if they failed to do so, while the regulations were formulated in such a detailed and rigid manner that neither medical nor social circumstances could be taken into account. It was forbidden to carry out an autopsy within twenty-four hours of death, but this rule was often amended to accommodate a post-mortem Caesarean section. ${ }^{16}$

From around 1800 until the late nineteenth century, Osiander and other obstetricians discussed various techniques in their search for medical alternatives to the section. These included manual extraction after podalic version had been carried out, or the use of forceps. ${ }^{17}$ But soon it became apparent that these techniques could be used only if the birth was imminent. The prerequisite was that the orifice of the uterus had to be almost open. The majority of practitioners continued on humanitarian grounds to refuse to perform a Caesarean section on a mother who was still alive, although this seemed to be the most likely way of delivering a live baby. ${ }^{18}$

To sum up, the situation at the beginning of the nineteenth century with regard to postmortem Caesarean section, which practitioners were legally obliged to carry out, was influenced by (a) traditional practices resulting from both Catholicism and philanthropy, (b) a lack of basic knowledge about this operation and the likelihood of a successful outcome and, most importantly, (c) the fact that there were no satisfactory alternatives.

The following examples from both German- and French-speaking countries demonstrate the medical and non-medical factors which caused the mythical Caesarean section performed on the dead mother to become de facto and de jure obsolete within a period of seventy years. This study, which is based on the history of the post-mortem Caesarean section, will also analyse the more general topic of the heuristic significance of medical statistics, which were gradually gaining ground against the traditional physiological and clinical knowledge of the time.

The radical change which characterized medical thinking in the nineteenth century enables us to divide the statistical demythologization of the post-mortem Caesarean section into three clearly defined stages, which, of course, did not occur in all countries at the same time:

\footnotetext{
15 See Jean Jacques Bruhier d'Ablaincourt, Abhandlung von der Ungewißheit der Kennzeichen des Todes und dem Mißbrauche, der mit übereilten Beerdigungen und Einbalsamierungen vorgeht. Aus dem Französischen übersetzt und mit Anmerckungen und Zusätzen vermehrt herausgegeben von $D$. Johann Gottfried Jancke. Leipzig and Copenhagen, Roth, 1754, pp. 23ff., 136, 207; Jean Louis Baudelocque, L'art des accouchemens, Paris, 1781, pp. 283-5.
}

\footnotetext{
${ }^{16}$ For example, the Preussische Verordnung des Polizei-Ministeriums on the prohibition of early autopsies from 6.11.1811 (see Schwarz, op. cit., note 12 above, p. 136f.).

${ }^{17}$ Survey in Johann Peter Heyman, Die Entbindung lebloser Schwangern mit Beziehung auf die Lex Regia, Koblenz, J K Hölscher, 1832, pp. $31-4$.

${ }^{18}$ See Pundel, op. cit., note 2 above, pp. 141-58.
} 


\section{The Post-Mortem Caesarean Section in the Nineteenth Century}

(1) A period of affirmation which produced only a few medico-political proposals for reform of the inappropriate and unrealistic legislation. These proposals were merely based on physiological theories or on an arbitrary accumulation of retrospective observations.

(2) A period of constructive criticism during which the need for reform of the legislation was established and an intensive search for legal alternatives was undertaken. This development was based on a methodical survey which led to the formulation of more accurate indications.

(3) A period of radical rejection which ignored the existing laws and the restrictions they imposed on the physician's freedom of medical practice. This process was based on the accumulation of various local statistics.

\section{Affirmation}

As Osiander's account of the death and delivery of the Spanish Queen demonstrates, this period was characterized by relative ignorance about post-mortem Caesarean section. Steps taken by the medical profession to improve the success of such operations were later supported by the state. As a first step, the conditions under which they took place were examined in detail. As early as the beginning of the eighteenth century, it was assumed that the cause of the mother's death played a decisive role in the prognosis of the unborn child. If she had spent days in the throes of death, or had suffered "convulsions" or from a consumptive disease, the chances of the child's surviving were thought to be slight, while a sudden death caused by external factors or Schlagfluss (apoplexy) was thought to increase the child's chances of life. ${ }^{19}$ However, there are no detailed accounts of any of these diseases dating from this time.

In $1827 / 28$ the medical faculty of the University of Tübingen held a competition in an attempt to rectify this lack of knowledge. The Württembergische Innenminsterium (Württemberg interior ministry) had previously asked the faculty for a medical report on "an adequate reform of the insufficient existing laws in Württemberg on post-mortem Caesarean sections". ${ }^{20}$ This competition prompted the collection and analysis of information on all cases of post-mortem Caesarean sections known to have been carried out. In 1828, the Württemberg authorities-obviously acting on the proposals made by the faculty-introduced several amendments to the Württembergische Medicinal-Ordnung (set of medical decrees) of 1755. In 1829 the doctoral thesis of the medical student L F Reinhardt was published. It was a revised version of the paper which had won the first prize in the competition. His research was widely commented on in specialist journals of that time. The table compiled by Reinhardt listed 119 cases (half of which were taken from literature published before 1800) including, for the first time, a methodical account of the following details: the condition of the mother before and during her pregnancy, the cause

\footnotetext{
${ }^{19}$ For example, see the amendment Eid und Pflicht einer Leichenfrau (oath and duty of women treating corpses) of the city of Heilbronn (15 Dec. 1772), paragraph 8f.; see also Johann Daniel Metzger, 'Sendschreiben an Herrn Hofrath und Professor [Christian Gottfried] Gruner, über Kaiserschnitt und Synchondrotomie', in Vermischte medizinische Schriften, vol. 3, Königsberg, Dengel, 1784,
}

pp. $373-432$, on p. 418 . There is a similar distinction in the Talmud, see L Fulda, 'Beytrag zur Geschichte des Kayserschnitts', Siebolds Journal für Geburtskunde, 1826, 6: 1-33, on pp. 9-10.

${ }^{20}$ L F Reinhardt, 'Der Kaiserschnitt an Toten', Diss. med. et chir., University of Tubingen, 1829, p. V. 
of death, the stage at which it had occurred during pregnancy, the amount of time which had elapsed between the death of the mother and the intervention and the success of the operation (Figure 1). However, Reinhardt's research, which he mainly used to confirm the general view of medicine at the time, was limited to two qualitative comments. First, there was no doubt that the operation could be successful and that a child could survive it. However, this was less likely "than is generally believed". Second, the sudden death of the mother considerably increased the chance of the fetus surviving for a longer period of time. However, Reinhardt could not name one cause of death which could be associated with better chances for the survival of the child because the more recent literature of his time only mentioned one successful case of a post-mortem Caesarean section. ${ }^{21}$

Reinhardt's research demonstrates that around 1830 little importance was attached to the gathering of clinical case histories on this question. From today's point of view, however, this attitude was justified, since the cases used by Reinhardt for clinical evaluation covered a period of two thousand years. He relied more on traditional medical beliefs and physiological speculations, which maintained that the operation could theoretically be successful, than on statistical evidence.

Nevertheless, the discrepancy between the traditional physiological theory and the latest medical practice, which for the first time was based on statistical data, led him to the conclusion that improvements were necessary. Some of his proposals were added to the already mentioned amendment to the Württembergische Medicinal-Ordnung of 1828. The first measure was that an amtliche Beihülfe der Polizeibehörden (official assistance from the police) was allowed, if necessary, to intervene in cases where relatives were opposed

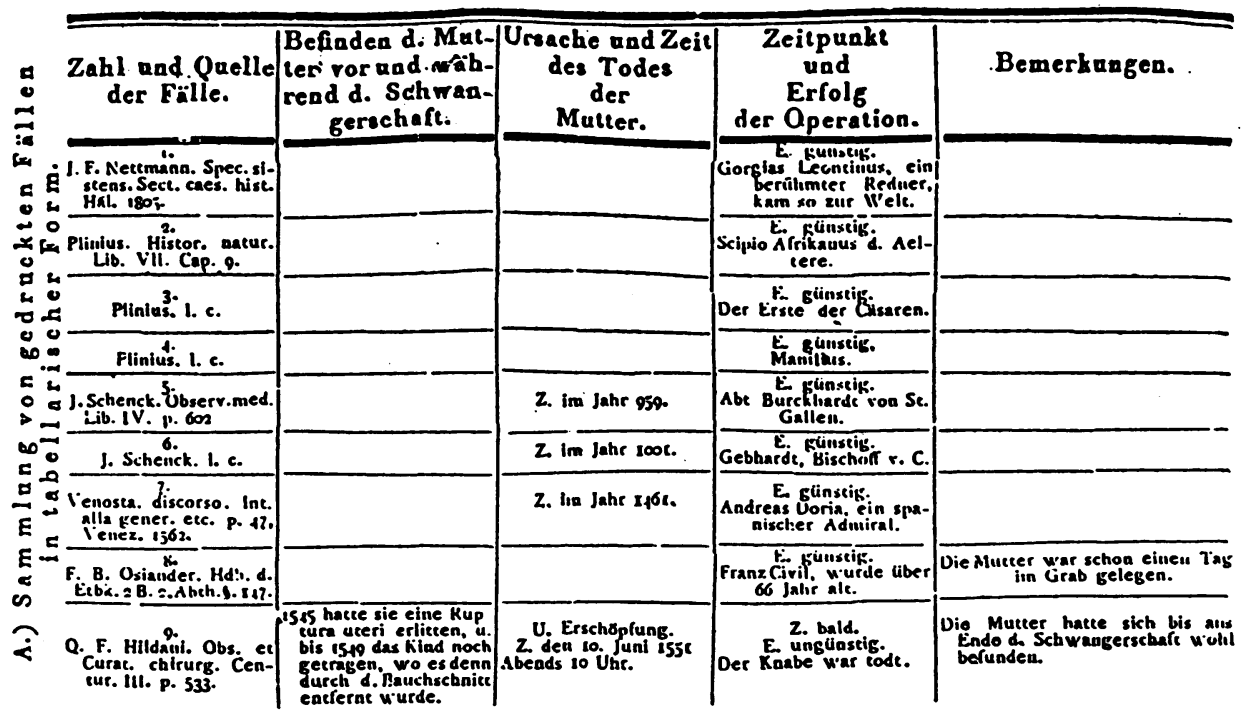

Figure 1: Table from L F Reinhardt, 'Der Kaiserschnitt an Toten', Diss. med. et chir., University of Tübingen, 1829, p. 81.

${ }^{21}$ Ibid., pp. 11, 19. 


\section{The Post-Mortem Caesarean Section in the Nineteenth Century}

to the operation. ${ }^{22}$ These were not uncommon; the surgeon Lorenz Heister ${ }^{23}$ and Johann Peter Frank, who was famous for dealing with questions on public health in general and post-mortem Caesarean section in particular, ${ }^{24}$ had already commented in writing on how objections on the part of relatives could affect the success of the operation. As late as the 1830s, relatives in the Prussian provinces of Pomerania and Posen prevented post-mortem Caesarean sections being carried out in four instances. Physicians were reprimanded or prosecuted for not performing this operation. ${ }^{25}$

In the introduction to Reinhardt's thesis, Leopold Socrates Riecke, professor of surgery and obstetrics at the University of Tübingen, supported Reinhardt's view that the general hostility towards this operation was to blame for its negligible success rate but also admitted that this negative Stimmung (atmosphere) was due to the operation's high failure rate.

In an effort to break this vicious circle, Riecke, in contrast to Reinhardt and the amendment of 1828 , did not advocate police protection for such operations. He suggested rather that the success rate of post-mortem Caesarean section could be increased and its reputation enhanced by the use of stricter medical indications for its performance. ${ }^{26}$ If the evaluation of empirical data indicated that the operation was unlikely to be successful, the law should no longer insist on its being carried out so unconditionally in every case. However, due to the lack of empirical facts, Riecke's cautious recommendation received little attention and was only partly included in the amendment. It was decided, after all, that in future the operation should be carried out within two hours of the mother's death and not before the twenty-eighth week of pregnancy. These restrictions, however, were not binding. In general, permission not to carry out the operation was granted only if it could be proved that the fetus was dead.

In an effort to defend the professional interests of physicians, the faculty also brought about a decree that prohibited non-medical people from performing the emergency intervention. However, this did not reduce the number of sections performed in vain. Even the amendment introduced in 1828 , which suggested the above-mentioned alternative delivery techniques, was able to prevent only a few post-mortem Caesarean sections from being carried out. ${ }^{27}$

Reinhardt and Riecke's additional proposal of a state bonus for every successful operation was ignored by the authorities of Württemberg. We can see from medical sets of decrees in other German states that the authorities tried to influence how often the operation was performed by fixing special taxes on private fees. The Lippische Medizinaltaxe in the County of Lippe of 21.3.1789, for instance, granted six taler to the surgeon if he delivered the child alive and only two taler if the baby died in childbirth. The Preussische Taxe (edict from 21.6.1815), on the other hand, was fixed at 4 to 8 taler and no mention was made of the success or failure of the operation. The scale of fees of the

\footnotetext{
22 Text of the amendments, ibid., pp. 57-9, paragraph 1.

${ }^{23}$ Lorenz Heister, Institutiones chirurgicae, Amsterdam, Janssonius-Waesbergius, 1739, p. 760.

${ }^{24}$ See Frank, op. cit., note 8 above, pp. 569-608, on pp. 587-90.

${ }^{25}$ See Wilhelm Lange, 'Kritische und statistische
}

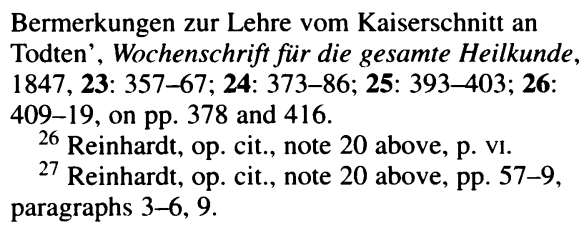

Bermerkungen zur Lehre vom Kaiserschnitt an Todten', Wochenschrift für die gesamte Heilkunde, 1847, 23: 357-67; 24: 373-86; 25: 393-403; 26 : 409-19, on pp. 378 and 416.

${ }^{26}$ Reinhardt, op. cit., note 20 above, p. vi.

${ }^{27}$ Reinhardt, op. cit., note 20 above, pp. 57-9, paragraphs $3-6,9$. 


\section{Daniel Schäfer}

Grand Duchy of Hesse of 14.8.1822 permitted charges of 15 guilder for the well-off and 5 guilder for the less well-off. In Baden the fees were covered by the state. ${ }^{28}$

\section{Constructive Criticism}

Johann Peter Heyman, Medizinalrat (public health officer) and midwifery teacher in Koblenz, continued his predecessor's systematic collection of case histories in a more methodical way. His action was prompted by his own bad experience of post-mortem Caesarean sections. In his publication of 1832 Heyman divided Reinhardt's data chronologically into three groups (until 1700, 1700 to 1800 , and after 1800) and added to the latter group 129 new cases taken from the Prussian Rhine Provinces which he had collected over a period of ten years. ${ }^{29}$ However, he only considered the findings after 1750 as valid. The results showed that in the cases before 1700,20 out of 32 babies survived for some time and in cases after 1800 only 5 out of 190 babies survived. Within this chronological division, Heyman also sorted his data according to the cause of the death of the mother, but refrained from commenting on his results. ${ }^{30}$ The devastating outcome led the author to believe that as many pregnant women, who had only seemed to be dead, died because of this operation, as children were saved, although he was unable to prove this hypothesis. ${ }^{31} \mathrm{He}$ therefore proposed that the existing laws be reformed yet again in order to correspond with the original intention of the Lex Regia. He recommended a delivery per vias naturales (by natural childbirth) in cases where there was any doubt whether the woman was really dead. If the orifice of the uterus was still closed, Heyman's recommendation was that it be opened by incision. ${ }^{32}$

For the first time, Heyman also established the frequency of post-mortem Caesarean sections (1:8000 pregnancies; see Figure 2). He was able to do this because he could use a population statistic listing absolute birth figures introduced in 1801 by the French occupiers of the Rhineland. ${ }^{33} \mathrm{He}$ also made use of relevant data collected by physicians and published in reports of the public health authorities and newly established medical journals. ${ }^{34}$ In some states, the law required that every post-mortem Caesarean section had to be reported directly to the authorities or to the physician responsible for the district. ${ }^{35}$ As this did not apply to the kingdom of Prussia, Heyman believed that the number of not

\footnotetext{
${ }^{28}$ See Schwarz, op. cit., note 12 above, p. 136f.;

Reinhardt, op. cit., note 20 above, p. 56.

${ }^{29}$ Heyman, op. cit., note 17 above, p. III.

30 Ibid., Appendix VI, tables A-C.

31 Heyman shared the view of Petrus Camper, Johann Peter Frank, Johann Daniel Metzger, Immanuel Gottlieb Knebel, Friedrich Meissner, L Fulda and others that to operate on a woman who seemed dead carried a relatively high risk; see Ignaz Düntzer, Die Entbindung verstorbener Schwangern in geburtshülflicher und forensischer Beziehung, Cologne, F C Eisen, 1845, p. 16.

32 Heyman, op. cit., note 17 above, pp. 52-4.

33 Although information about birth rates in France (including the French occupied Rhineland) was available after the year 1801, various German
}

states only began to keep such records in 1817 . The total figure of infants who did not survive their first year of life was collected in the kingdom of Bavaria in 1836; this is the earliest population statistic of this kind in Germany (analysed by Brian R Mitchell, European historical statistics 1750-1970, New York, Macmillan, 1975, pp. 104-34, tables B6 and B7).

${ }^{34}$ Heyman (op. cit., note 17 above, pp. III, 11) mentions both the commitment of the authorities and official sources and the readiness of physicians to contribute to the collection of case histories.

${ }^{35}$ For example, Baden, Lippe-Detmold, HesseKassel, Saxony; see Reinhardt, op. cit., note 20 above, pp. 50-6. Schwarz, op. cit., note 12 above, p. 136. 


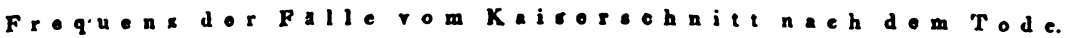

Die Gesammt-Berölkerung der besagten Prorinzon betrug am Schlusso des Jahren 1828 die Summe ron $2,172,545$.

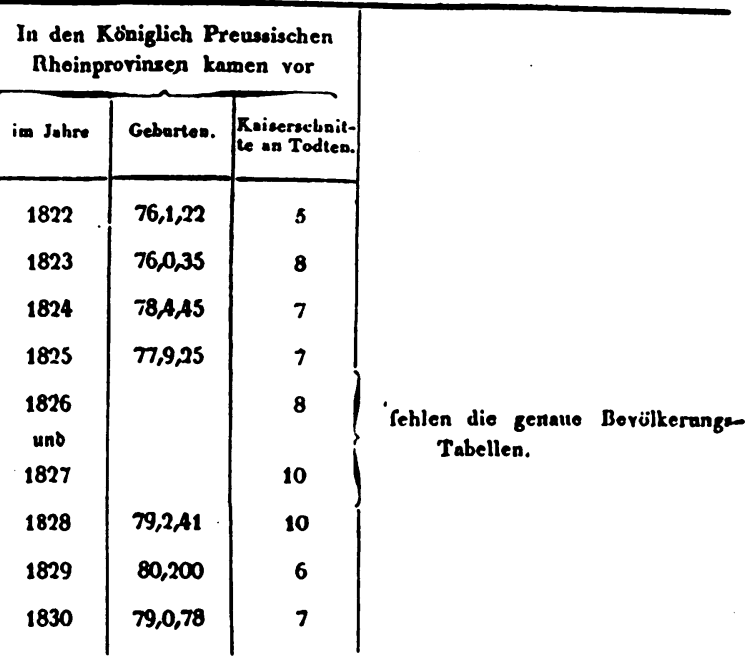

Es ergibt sich aus dieser Uebersicht, dass die Frequens der Fulle sich siemlich gleich bleibt; und nimmt man das Jahr 1828 als Norm an, so knme ohngefahr aut 8000 Schwangerschedten, Einmul der Tod der Schwangern in den letzten Monaten. Indesson darf man mit Wahrechoinlichkoit vorausutellea, dess bei dem gegenwärtigen beachtungslosen Stando der Gesetzo über dio Entbindung lebloser Schwangern, wenigstens die Halfe der Falle unbekennt bleiben.

Figure 2: Fig. C from Johann Peter Heyman, Die Entbindung lebloser Schwangern mit Beziehung auf die Lex Regia, Coblenz, J Hölscher, 1832, app. VI.

officially known cases of post-mortem Caesarean sections matched at least his number of collected cases. ${ }^{36}$

Heyman's hypotheses seem quite clear, even nowadays, because his research is based on a more critical evaluation of figures and on calculations. However, his use of only a small number of cases and the absence of a legal basis for their collection still gives his research a speculative aspect on which he does not comment.

His criticism of the alleged ${ }^{37}$ commitment to practising the post-mortem Caesarean section in Prussia was not, as one might think, based primarily on its lack of success, which his statistics proved, but rather on the physicians' difficulty in establishing whether the woman was really dead. Despite the negative figures, Heyman was, in principle, convinced that unborn children could be saved after the death of the mother and still approved of the practice of post-mortem Caesarean section, provided that it could be

\footnotetext{
${ }^{36}$ Heyman, op. cit., note 17 above, Appendix VI, table $\mathrm{C}$ (final comment).

${ }^{37}$ As Lange (op. cit., note 25 above, pp. 410-18) correctly observed, Heyman and later Moritz Landsberg ('Bemerkungen über den Kaiserschnitt an der Leiche', Adolph Henke's Zeitschrift für die Staatsarzneikunde, 1846, 52 (4): 367-89) misinterpreted the law: the Preussische Allgemeine Landrecht (Teil II, Tit.20, §737; cited in Schwarz, op. cit., note 12 above, p. 136), in contrast to the
}

original Lex Regia, specified only the means which should be undertaken to ensure the survival of the child after the death of the mother. Only the earlier mentioned Polizeiverordnung (see note 16 above) allowed a post-mortem Caesarean section to be carried out by a specialist within the first 24 hours of the mother's death as long as the baby seemed capable of surviving and could be delivered any other way, but this was not obligatory. 


\section{Daniel Schäfer}

established beyond doubt that the mother was dead. Heyman's only recommendation was that the operation should not be carried out during the first half of the pregnancy. ${ }^{38}$

Like Heyman, the Berliner Staabsarzt (physician to the military staff in Berlin) Wilhelm Lange also accepted Prussia's existing laws despite his devastating criticism of the older and negative survey of the newer case histories; according to his statistics, which included 141 new cases since the publication of Heyman's work, only three children remained alive for some time. ${ }^{39}$ In an effort to improve the results, he even called for the section to be carried out up to seven hours after the death of the mother. Lange cited health reports of medical colleges from the Rhine Province, Westphalia, Silesia, the province of Prussia, Posen, Brandenburg, Pomerania, Saxony and Nassau covering a period between 2 and 15 years. He came up with figures of 0.07 and 1.4 known cases of post-mortem Caesarean sections per year within these states. Unlike Heyman, he put this figure into perspective by comparing it with the total population figure. Nassau with 380,000 inhabitants had 1.2 post-mortem Caesarean sections per year, a five to six times higher prevalence rate of this operation than the Rhine province ( 1.4 sections per year with $2,287,000$ inhabitants). The author attributed these variations to differences among medical decrees, which affected the intervention itself as well as the exactness and regularity of the health reports. ${ }^{40}$

The first statistical studies of post-mortem Caesarean section led to a consensus in scientific literature in German that restrictions had to be imposed on the operation, although these studies refrained from demanding radical legislative changes. As early as 1839, an article in the Encyclopädisches Wörterbuch der medicinischen Wissenschaften by Karl Christoph Hüter, a professor of obstetrics in Marburg, mentioned strict indications for sections on dead pregnant women, in particular that the operation should not be carried out before the twenty-ninth week of pregnancy. ${ }^{41}$

\section{Rejection}

In the eighteenth century and mainly in Anglo-American countries, new therapies and methods, which had been developed for epidemic control, inoculation and in the area of pharmacology, were examined statistically on the basis of a small number of case histories. ${ }^{42}$ In the same way, established therapies (e.g. blood-letting as a treatment for fevers; and podalic version and extraction of the fetus as a treatment for haemorrhage during delivery) were examined with the help of arithmetic observation. ${ }^{43}$ This method, however, was generally based on mortality rates. ${ }^{44}$

\footnotetext{
${ }^{38}$ Heyman, op. cit., note 17 above, pp. 53-7. J A Seulen proposed a similar argument in "Ansichten über die Entbindung schwangerer Personen nach dem Tode in den letzten Monaten der Schwangerschaft', Neue Zeitschrift für Geburtskunde, 1835, 2: 11-17.

${ }^{39}$ Lange, op. cit., note 25 above, p. 377.

40 Ibid., pp. 377-9.

${ }^{41}$ Encyclopädisches Wörterbuch der medicinischen Wissenschaften, Berlin, J W Boike, 1839, vol. 19, p. 310 .

${ }^{42}$ See Edmund A Gehan and Noreen A Lemak, Statistics in medical research, New York and London, Plenum Medical Book Company, 1994, pp. 5-11, 29-31.
}

\begin{abstract}
${ }^{43}$ On the genesis of demographic and medical statistics, see J Rosser Matthews, Quantification and the quest for medical certainty, Princeton University Press, 1995, pp. 8-85; Gehan and Lemak, op. cit., note 42 above, pp.11-29. For the development in Britain, see Ulrich Tröhler, 'Klinisch-numerische Forschung in der britischen Geburtshilfe 1750-1820', Gesnerus, 1981, 38: 69-80; idem, "“To improve the evidence of medicine": arithmetic observation in clinical medicine in the eighteenth and early nineteenth centuries', Hist. Philos. Life Sci., 1988, Suppl., 10: 31-40.

${ }^{44}$ See Tröhler, "'To improve the evidence of medicine"', op. cit., note 43 above, pp. 32f., 37; idem, 'Klinisch-numerische Forschung', pp. 70, 74.
\end{abstract}


The debate on descriptive statistics also took place on the Continent between 1830 and 1850 , somewhat later than in Britain. ${ }^{45}$ The Parisian clinician Pierre Charles Alexandre Louis, who was also the founder of the Société Médicale d'Observation, promoted the méthode numérique as the basis for all medical research. He used this method to produce studies on phthisis (consumption), various feverish illnesses and on the effect of bloodletting, which to some extent contradicted the nosological systems and therapy of clinical medicine in use at that time. ${ }^{46}$ His method was severely criticized in a debate among surgeons at the Académie des Sciences of Paris in 1835. At the end of this very emotional and subjective discussion, the participants agreed that statistics could be of vital importance only in the fields of hygiene and epidemiology. With regard to clinical medicine the method had no relevance because probabilities could not replace the reliability of therapeutic experiences. ${ }^{47}$

In Germany it also took some time for these methods to become common practice. As J Rosser Matthews explains, debates about the clinical or experimental importance of statistics were taking place in various countries "at precisely the moment in time when that country was in a period of medical and/or scientific ascendancy". ${ }^{48}$ In Germany, this development was at first concentrated in the area of university-based physiological research and was stimulated in 1840 by Jules Gavarret's book on a mathematical theory of probability in medicine. ${ }^{49}$ At the same time, people started to look at speculative theories about the autonomous status of the fetus in a more critical light. ${ }^{50}$ In his inaugural lecture in Leipzig in 1851, one of the publishers of the Archiv für physiologische Heilkunde Carl August Wunderlich criticized the "therapeutic anarchy" of contemporary medicine, which did not obey the rules of scientific research. In contrast to Louis' approach, he called for "mass observations", a Statistik which would still take into account the patient's individual history. 51

Around the middle of the century, the annual reports of lying-in hospitals and institutions became the main source of statistical data which contained more and more quantitive and differentiated obstetrical information. In 1855, Carl Sickel, a physician

\footnotetext{
${ }^{45}$ As early as 1789 a register of deaths listed by diseases was compiled for London based on the Bills of Mortality in use since 1600; see William Black, An arithmetical and medical analysis of the diseases and mortality of the human species (London, 1789), facsimile, Farnborough, Gregg International Publishers, 1973.

46 See Erwin H Ackerknecht, Medicine at the Paris Hospital 1794-1848, Baltimore, John Hopkins Press, 1967, pp. 9f., 102-4; Terence D Murphy, 'Medical knowledge and statistical methods in early nineteenth-century France', Med. Hist., 1981, 25 : 301-19, on pp. 310-12; Rosser Matthews, op. cit., see note 43, pp. 14-38. According to James Jackson, an American student of Louis, Louis was greatly influenced by the experimental physiologist George Fordyce (1736-1802). See Gehan and Lemak, op. cit., note 42 above, pp. 31-6.

${ }^{47}$ See Ulrich Tröhler, 'Die therapeutische "Erfahrung": Geschichte ihrer Bewertung zwischen subjektiv sicherem Wissen und objektiv
}

wahrscheinlichen Kenntnissen', in J Köbberling (ed.), Die Wissenschaft in der Medizin, Schattauer, Stuttgart, New York, 1993: 65-81, on p. 70f.; idem, "“To improve the evidence of medicine",

op. cit., note 43 above, pp. 38f.; Murphy, op. cit., note 46 above, pp. 312-17.

${ }^{48}$ Rosser Matthews, op. cit., note 43 above, p. 3.

${ }^{49}$ Ibid., pp. 46-7.

${ }^{50}$ Benjamin Ridge (Physiology of the uterus, placenta and foetus: with observations on the membra meconii and rete vasculare, London, J Churchill, 1845), for example, believed that the fetus was completely independent of the mother's womb (according to Lange, op. cit., note 25 above, p. 396). See also note 71 below.

${ }^{51}$ C A Wunderlich, 'Ein Plan zur festeren Begründung der therapeutischen Erfahrungen; Antrittsvorlesung gehalten zu Leipzig d. 12. März 1851', Schmidt's Jahrbücher der in- und ausländischen gesammten Medicin, 1851, 70: 106-11. 


\section{Daniel Schäfer}

from Leipzig, compiled the first comprehensive and uncommented list of these figures based on an analysis of a total of 12,000 deliveries in various continental clinics and institutions. In the introduction to his study he explained that the unquestionable benefit of such statistical reports could "in principle be enhanced depending on the quantity of the analysed data". Sickel was also able to present data on obstetrical operations but not on Caesarean sections. ${ }^{52}$ At the end of his study he suggested that the annual reports should adhere to a common standard in order to facilitate compiling such a list. This common standard also referred to the post-mortem operation. In 1859 Sickel published another register which now also mentioned figures about the Caesarean section. Of over 400,000 world-wide registered deliveries almost 100 were performed by Caesarean section; out of this small number at least four-fifths were post-mortem, which led Sickel to the conclusion that on average one in every 5,400 deliveries was performed by Caesarean section. However, no fetus was delivered alive. ${ }^{53}$

Bearing these figures in mind, it is easy to understand why several authors, who had already compiled similar data of unsuccessful deliveries, began at the beginning of the 1860 s publicly to demand the abrogation of the laws which obliged practitioners to carry out post-mortem Caesarean sections. ${ }^{54}$ As an example, Emil Apollo Meissner presented the assembly of the Leipziger Gesellschaft für Geburtshülfe on 16 July 1861 with 20 cases of post-mortem Caesarean sections that had been performed between 1830 and 1860, none of which had delivered a live child. ${ }^{55}$ The authors referred to Prussia's 1851 penal code which did not mention any obligation on the part of the physician to deliver the child of a dead pregnant woman or to carry out a post-mortem Caesarean section (in contrast to the Allgemeine Landrecht which was in force until then). ${ }^{56}$ In Baden, Denmark and earlier on in Hamburg, the legal regulations were also discarded. ${ }^{57}$

In 1861 the Kurhessischer Medizinalrat (public health officer of Electoral Hesse) Ignaz Schwarz published figures about the frequency of this operation. One post-mortem Caesarean section was performed for every 3240 deliveries, according to official tables dating from 1836 to 1848 . From his 107 cases of post-mortem Caesarean sections, yet again, not one single fetus had been delivered alive. ${ }^{58}$ With reference to the officially reported "success story" of this operation Schwarz could not resist asking ironically: "Have the obstetricians become more honest or less skilled?" In view of the legal situation, the physician was confronted with the dilemma of either letting unborn children

\footnotetext{
${ }^{52} \mathrm{C}$ Sickel, 'Bericht über die Ereignisse in mehreren Gebäranstalten, geburtshülflichen Kliniken und Polikliniken', Schmidt's Jahrbücher der in- und ausländischen gesammten Medicin, 1855, 88: 101-17.

${ }^{53} \mathrm{Idem}$, 'Bericht über die Ereignisse in mehreren Gebäranstalten, geburtshülflichen Kliniken und Polikliniken', Schmidt's Jahrbücher der in- und ausländischen gesammten Medicin, 1859, 104: 105-16.

${ }^{54}$ An exception is Landsberg (op. cit., note 37 above, p. $388 \mathrm{f}$.) who as early as 1846 had publicly demanded an abolition of these laws (though without statistical proof).

55 Emil Apollo Meissner, 'Ueber

Leichenentbindungen', Monatsschrift für
}

Geburtskunde und Frauenkrankheiten, 1862, 20:

40-62.

56 See note 37 above.

57 See Otto Dicke, 'Der Kaiserschnitt an verstorbenen Schwangern', Diss. med., University of Bonn, 1903, p. 9; Schwarz, op. cit., note 12 above, p. 136f.; Lange, op. cit., note 25 above, p. 410.

58 Rudolf Dohrn continued the collection of such cases in Electoral Hesse between 1852 and 1866. Ninety cases documented by him did not include one single instance of the baby being born alive; see Rudolf Dohrn, Der Kaiserschnitt an verstorbenen Schwangeren, Sammlung klinischer Vorträge, N. F. Nr.188 (Gynäkologie Nr. 69), Leipzig, Breitkopf \& Härtel, 1897, pp. 987-1000, on p. 989. 


\section{The Post-Mortem Caesarean Section in the Nineteenth Century}

die while having to wait for the mother's death or being criticized for performing a Caesarean section on a mother who was still alive. ${ }^{59}$

Schwarz was never able to discover why the total annual case figures varied so much: from 3 to 16 . With the help of probability calculus these figures can nowadays be easily explained as random dispersion. However, Schwarz did discover that with such a small number of post-mortem Caesarean sections only a tiny minority of obstetricians had had personal experience of this operation, ${ }^{60}$ particularly as the number of obstetricians had more than doubled within Electoral Hesse between 1820 and 1860 .

Like his predecessors, Schwarz could not resist the temptation to explain the frequent death of the unborn child using physiological reasons that ignored his statistical evidence. This physiological line of argument was based on the antiquated assumption that mother and child shared a diaplacental blood circulation and that the death of the mother would automatically be followed shortly afterwards by the death of the child. ${ }^{61}$ It was thought that all the child's blood was pumped into the body of the mother, and that the child died within a few minutes as a result of this enormous loss of blood, assuming that a child had a pulse of $120-140$ beats per minute.

\section{The Situation in France}

The debate on the post-mortem Caesarean section was taking place in France at the same time, where it was also characterized by a relative lack of knowledge of the physiological conditions of the unborn child. At a conference on this topic held at the Académie de Médecine in Paris in 1861, participants still based their discussions on traditional arguments which were no longer relevant in Germany. Jean Alexandre Le Jumeau de Kergaradec, who was an authority on the subject of auscultation of fetal heart beats, deserves particular mention. ${ }^{62}$ His belief that the unborn child could survive in the womb for a considerable length of time after the death of the mother was based on numerous historical single case histories. ${ }^{63}$ In contrast, the opponents of intervention could use only arguments based on their own experiences which, due to the low number of post-mortem Caesarean sections performed, were limited. In the end, the Académie reached a compromise by which physicians would, in consultation with the relatives, use their own judgement to decide when to carry out a post-mortem Caesarean section. There would be no legal restrictions on its

\footnotetext{
${ }^{59}$ Similarly, Ignaz Düntzer, a surgeon and obstetrician practising in Cologne, had discussed twenty years previously the ethical conflict arising in situations where a choice had to be made between the life of the mother and that of the child. The child could sometimes be saved by a Caesarean section, which represented a threat to the life of the mother, while the child's life was at risk from perforation of the head if the Caesarean was not carried out. See Ignaz Düntzer, Die Competenz des Geburtshelfers über Leben und Tod, mit besonderer Rücksicht auf die Streitfrage: Darf in zweifelhaften Fällen das Kind der Mutter, oder die Mutter dem Kinde geopfert werden?, Cologne, J P Bachem, 1842.

${ }^{60}$ Schwarz, op. cit., note 12 above, p. $167 f$.
}

\footnotetext{
${ }^{61}$ As early as 1579 Giulio Cesare Aranzio rejected Galen's theory of the fetus receiving its mother's blood and spirit via the placenta (see Heinrich Fasbender, Geschichte der Geburtshülfe [Jena 1906], Reprint Hildesheim, Georg Olms, 1964, pp. 51, $111 \mathrm{f} ., 152 \mathrm{f}$.). In his Exercitationes de generatione animalium (note 10 above) William Harvey proved that the fetus of the mammal had an independent circulation. See also note 50 above and note 71 below.

62 Biographisches Lexikon hervorragender Ärzte aller Zeiten und Völker, ed. August Hirsch, Munich, Urban \& Schwarzenberg, 1962, vol. 3, p. 506.

${ }^{63}$ Abstract in Gazette des Hopitaux, 1861, 5 (12 Jan.).
} 


\section{Daniel Schäfer}

performance. ${ }^{64}$ Unlike their German contemporaries, ${ }^{65}$ they could not agree on the introduction of counter-indications for the operation, such as that it should not be carried out before the twenty-eighth week of pregnancy, or indications for alternative post-mortem methods of delivery (it took another six months-thirty years after the publication of Heyman's book-before Salomon Jonas Otterbourg recommended a delivery per vias naturales by incision of the orifice of the uterus). ${ }^{66}$ This agreement did not come about, mainly because almost no statistical data had been considered, apart from that of Charles Devilliers. In 1861 he presented a list of 48 cases which he had already partly used in his doctoral thesis De l'hystérotomie après la mort de la mère (Paris, 1838) ${ }^{67}$ His results were quite varied: 10 children survived the mother (in some cases up to 24 hours). Furthermore, the influence of the Roman Catholic church on the ethics of obstetrics in France seems to have been still quite strong, at least on this question, although secularization had long since been achieved. ${ }^{68}$ According to the Catholic Church, every Catholic had a personal responsibility for the spiritual salvation of the unborn. Kergaradec based his arguments especially on this requirement of the Church and quoted at length examples from the works of the previously-mentioned theologian Cangiamila. Even the chairman of the Académie, $\mathbf{J}$ A H Depaul, recommended intrauterine baptism by the injection of baptismal water as an alternative to the religiously motivated post-mortem Caesarean section in order to save the soul of a baby before the seventh month. In 1740, Pope Benedict XIV had given permission for such a provisional baptism (sub conditione) to be carried out. ${ }^{69}$

In spite of the various preconditions and the different emphasis, this divided position in France can be compared with the acceptance of post-mortem Caesarean operations in German medical circles around 1830 because the knowledge of the statistical success rate was at a similar stage of development in the two countries.

A relatively positive attitude towards post-mortem Caesarean section was also apparent in other southern European countries in the second half of the nineteenth century. A study published in Catholic Italy showed that out of 8352 deliveries, 21 post-mortem Caesarean sections were carried out, which gives the very high frequency of 1:400. The results compared to those of Central Europe were no different. A statistical register of the cities of Milan, Cremona and Venice shows that out of 116 babies, only two were delivered alive and they both died within four days. ${ }^{70}$

\footnotetext{
${ }^{64}$ For more details on the discussion at the conference of the Académie de Médecine see Gazette des Hopitaux, 1861, 10 (2 Jan.), 40 (4 Apr.), 43 (11 Apr.; documentation of the conference), 44 (13 Apr.), 45 (16 Apr.), 46 (18 Apr.), 47 (20 Apr.), 49 (25 Apr.), 52 (2 May), 54 (7 May), 55 (11 May). A summary of the discussion from a German point of view is provided by Ferber, 'Ueber den Kaiserschnitt and der Todten', Schmidt's Jahrbücher der in- und ausländischen gesammten Medicin, 1863, 117: 179-89; see also the anonymous report in Monatsschrift für Geburtshülfe und Frauenkrankheiten, 1861, 18: 396-405.

${ }^{65}$ See note 41.

${ }^{66}$ Gazette des Hopitaux, 1861, 106; see Ferber, op. cit., note 64 above, p. 187.

${ }^{67}$ L'Union médicale, 1861, 35/36 (23 Mar.).
}

According to Lange (op. cit., note 25 above, p. 379) only one out of 32,221 children was delivered by Caesarean section (possibly on a mother who was still alive) in a Parisian maternity hospital between 1835 and 1845 . This indicates most probably insufficient documentation.

${ }^{68}$ Gazette des Hopitaux, 1861, 44 (13 Apr.); see Schäfer, Geburt aus dem Tod, op. cit., note 2 above, p. $127 \mathrm{ff}$.

${ }^{69}$ For a discussion of intrauterine baptism see Jean Verdier, La jurisprudence particulière de la chirurgie en France ou Traité historique et juridique ...., Paris, 1764, vol. 2, p. 656f.

${ }^{70}$ Abstract from Alfonso Corradi, 'Ostetricia in Italia', in Schmidt's Jahrbücher der in- und ausländischen gesammten Medicin, 1877, 175: 215. 


\section{The Post-Mortem Caesarean Section in the Nineteenth Century}

\section{Subsequent Developments}

Meanwhile, within Germany, criticism and rejection of this operation continued and, as already mentioned, physiological examinations were becoming more and more important and gradually replaced the speculative approach. As early as 1845, Casimir Grynfellt published the results of a series of animal experiments which helped him to demonstrate that the movements made by the fetuses in the womb could continue up until thirty minutes after the death of the mother. ${ }^{71}$ Because of the speculative nature of his conclusions regarding the respiration and nourishment of the fetuses, Grynfellt's work was practically ignored in the German-speaking area.

In 1864 a major breakthrough in discovering the physiological conditions of the unborn child was made by Bernhard Breslau, at this time a professor of gynaecology and obstetrics in Zurich. His animal experiments, carried out as part of a competition held by the medical faculty of the University of Zurich, showed that fetuses of mammals survived the death of their mother for some minutes only, regardless of how the mother had died. ${ }^{72}$ This competition had in fact been instigated by Breslau himself, whose personal interest in the subject was stimulated by the discussion at the beginning of the 1860 s and by his own experience. Four years previously he had carried out such an operation in the canton of Zurich. Although the mother had been dead for at least 15 minutes, he was still able to deliver a live, although premature child. ${ }^{73}$

Breslau's experiments received a good response in medical circles and his findings were confirmed by the experiments of Max Runge, professor of obstetrics and gynaecology in Dorpat und Göttingen, among others. ${ }^{74}$

In view of the critical discussion in the 1860 s, it was no surprise that the German Reichsstrafgesetz of 1871 (penal law of the Empire), which was modelled on that of Prussia, no longer made any mention of the post-mortem Caesarean section. However, physicians in the Catholic dominated countries of the Habsburg monarchy, and later those practising in the first Austrian Republic still had to carry out the intervention. ${ }^{75}$ Under the banner of the Kulturkampf (the struggle between state and church on such issues as registry office versus church weddings and religious education in schools), anti-Catholic and positivistic forces in Prussia, Baden and Hesse prevented a further public debate on this topic. None the less, post-mortem Caesarean section was still the subject of various dissertations and studies written between 1875 and 1927. These works presented even better statistical results, with chances of survival ranging from 40 to 70 per cent, based on a register of more recent single case histories. ${ }^{76}$ However, it was now known that "many

\footnotetext{
${ }^{71}$ Revue Médicale Française et Étrangère, October 1845, see abstract from Robert Küttner, 'Untersuchungen über die Ernährung des Fötus', Schmidt's Jahrbücher der in- und ausländischen gesammten Medicin, 1846, 52: 285f.

72 Bernhard Breslau, 'Experimentelle Untersuchungen über das Fortleben des Fötus nach dem Tode der Mutter', Monatsschrift für Geburtskunde und Frauenkrankheiten, 1864, 24 : 81-102.

${ }^{73}$ Idem, 'Kaiserschnitt nach dem Tode. Lebendes Kind', Monatsschrift für Geburtskunde und Frauenkrankheiten, 1862, 20: 62-9.
}

\footnotetext{
${ }^{74}$ See Dohrn, op. cit., note 58 above, p. 995 f.

${ }^{75}$ See Hans Otto Neumann, 'Sectio caesarea in mortua et in moribunda', Zeitschrift für Geburtshilfe und Gynäkologie, 1929, 94: 749-57; R Rheindt, 'Der Kaiserschnitt an der Toten', Wiener klinische Wochenschrift, 1942, 55: 251-5, on p. 254.

${ }^{76} \mathrm{~K}$ Prunnhuber, 'Über Entbindung verstorbener Schwangerer mittels des Kaiserschnittes', Diss. med., University of Munich, 1875; Ludwig von Winckel, 'Der Kaiserschnitt an der Toten und an der Sterbenden', Ärztliche Rundschau, 1892, 2 (5): 49-55; Erwin Silber, 'Das Überleben der Frucht und der Kaiserschnitt an der Toten', Diss. med.,
} 
cases of stillborn children were just not published"77 (positive selection). In addition, most of the sections were now carried out in accordance with clinical conditions and with a strictly limited indication, i.e. in the eighth or ninth month of pregnancy, and not more than twenty minutes after the mother's death. Moreover, after 1880, there were many successful cases of Caesarean sections on a live mother, provided they were carried out in time. This operation thereby established itself as an alternative to post-mortem Caesarean section, which had become the least frequent obstetrical operation of all by the end of the twentieth century. ${ }^{78}$

However, even now, studies are still carried out to establish the statistical success of a post-mortem Caesarean section based on a world list of case histories. ${ }^{79}$ From a purely statistical point of view, these efforts are doomed to failure because of the small number of local case figures and the varying indications.

\section{Assessment of the Declining Practice of the Post-Mortem Caesarean Section within a Scientific Historical Context}

The history of the post-mortem Caesarean section in the nineteenth century demonstrates the possibilities, limits and the increasing influence of an empiricostatistical based argumentation within clinical practice. However, the results achieved by arithmetic observation had at first no impact on traditional medical beliefs and nonmedical factors such as legal and moral obligations. Even in France, where some exceptional and pioneering studies had been published in the first decades of the nineteenth century, the use of medical statistics in clinical practice still remained very limited until well into the second half of the century. At the start of the 1860s, Armand Trousseau, a prominent member of the Sociéte Médicale d'Observation, "explicitly rejected Louis's claim, that the clinical physician should become a kind of empirical scientist." 80 The majority of physicians, especially those influenced by convention, law and denomination, still adhered to traditional concepts of therapy. Religion had the most

\footnotetext{
University of Leipzig, 11 Oct. 1895; Bauer-Stettin, 'Sectio caesarea post mortem', Monatsschrift für Geburtshülfe und Gynäkologie, 1902, 16: 811-15; Dicke, op. cit., note 57 above; Josef Böhmer, 'Über den Kaiserschnitt an der Toten und an der Sterbenden', Diss. med., University of Giessen, 1908; Anna Sebold, 'Über die Sectio caesarea in mortua', Diss. med., University of Heidelberg, 1916; Johannes Baekmann, 'Sectio caesarea in mortua', Diss. med., University of Cologne, 30 May 1922; Karl Kupfer, 'Der Kaiserschnitt an der Toten', Diss. med., University of Leipzig, 24 Nov. 1927. The subsequent debate in the United States was dominated by the following contributions: E L Duer, 'Post-mortem delivery', Am. J. Obstet. Dis. Women Child., 1879, 12: 1-22; Cesar Garezky, 'K voprosu o prodoljitelnosti vnutriutrobnoi jizni ploda poslic smerti materi' (Caesarean section after the death of the mother), Diss. med., University of St Petersburg, 1877; Abstract in Medical and Surgical Reporter
}

(Philadelphia), 23 Aug. 1879, 12: 166; R P Harris, Am. J. Obstet. Dis. Women Child., 1881, 14: 341-61. Duer also analysed data of the eighteenth century and came up with 35 survivals out of 55 postmortem Caesarean sections. Garezky, using data collected in St Petersburg, reported that only 34 successful deliveries took place out of 379 Caesarean sections. Among those 34 babies born alive only 5 managed to survive for a longer than a few days.

77 Sebold, op. cit., note 76 above, p. 18.

78 J Meinert, 'Die Sectio in mortua', Geburtshilfe und Frauenheilkunde, 1982, 42: 310-12, on p. 310.

${ }^{79}$ Dario Merchan López, 'Cesárea post-mortem', Revista de obstetricia y ginecología de Venezuela, 1968, 28: 29-146; Charles E Weber, 'Post-mortem Caesarean Section', Am. J. Obstet. Gynec., 1971, 110: 158-65; Vern L Katz, Deborah J Dotters and William Droegenmueller, 'Perimortem Caesarean Delivery', Obstet. Gynec., 1986, 68: 571-6.

${ }^{80}$ Rosser Matthews, op. cit., note 43 above, p. 67. 


\section{The Post-Mortem Caesarean Section in the Nineteenth Century}

influence on this operation and this makes generalizations about the role of the scientific heuristics in clinical practice particularly difficult.

In Germany, the statistical evaluation of therapies led, after 1830, to the establishment of more precise indications and counter-indications for an intervention. This can be seen as part of a general trend towards seeing therapeutic treatment in a more objective light with the help of scientific methods. But, it was only after 1860 , just before the introduction of thermometry, ${ }^{81}$ sphygmography, ${ }^{82}$ and weight measuring, which all used numerical data to determine treatment, that physicians openly declared their opposition to the existing laws for the performance of post-mortem Caesarean sections which restricted their freedom of practice and therapeutic choice. It must be said, however, that not only statistic-based and physiological arguments, but also alternative therapy concepts and animal data were always included in this debate. The opponents of post-mortem Caesarean operations also profited from the political climate of the nineteenth century which allowed for laws to be amended in accordance with new findings.

Furthermore, it is obvious that the quality of early medical statistics depended to a great extent on the methodical standards and basic data from population statistics. The figures relating to this operation resulted from decrees introduced around 1800 which prescribed that in the case of the death of a pregnant woman the physician had to perform a Caesarean section and document it. In Germany especially this legislation was used as a statistical instrument which could help to discredit the measure originally imposed.

Secularization was a particularly strong force in the German-speaking world. The critical reaction of the German doctors at the conference at the Académie de Médecine in Paris $^{83}$ shows repeated evidence of their fundamentally positivistic and anti-clerical position, which was obviously a driving force in their opposition to the intervention.

Despite the influence of these additional factors, the dawn of medical statistics indicates fundamental changes in heuristics after 1800. These were the rejection of traditional beliefs founded on theories deriving from philanthropic concepts and single case histories; and the acceptance of scientific and systematic research based on the collection and control of facts and their visual representation in form of tables and diagrams.

The complete acceptance of statistical methods in all areas of medical practice has, however, even now, not been fully achieved.

\footnotetext{
${ }^{81}$ See R Vollmann, 'Die Anfänge der klinischen Thermometrie', Ciba Z. (Wehr/Baden), 1957, 8 (87): 2904-10.

82 See Roger Rullière, 'Geschichte der Kardiologie im 19. und 20. Jahrhundert', in Richard Toellner (ed.), Illustrierte Geschichte der Medizin, Salzburg, Andreas, 1990, vol. 3, pp. 1216-75, on pp. 1221, $1228 \mathrm{f}$.

${ }^{83}$ See commentary of L Posner, Allgemeine Medicinische Central-Zeitung, 1861, 30: 40 (he judges the discussion to be "one of the most
}

\author{
interesting advances in French medicine" and \\ considered Kergaradec to be a "cunning rogue"). \\ Ferber (op. cit., note 64 above, p. 179) regarded \\ intrauterine baptism as "inspired satire". In Prussia a \\ Regulativ (rule) from 1875 forbade autopsies within \\ 24 hours of death, without mentioning any exception \\ for the post-mortem Caesarean section. On 4 \\ December 1908 midwives were forbidden to carry \\ out intrauterine baptism with boiled water, \\ supposedly for hygienic reasons, see Schäfer, Geburt \\ aus dem Tod, op. cit., note 2 above, pp. 159.
}

